\title{
A Unicenter Study About The Frequency of Hypokalemia and The Frequency of High Creatinine Levels In Hematology Inpatient Unit
}

\section{Hematoloji Yatan Hasta Servisinde Hipokalemi Sıklığı ve Yüksek Kreatinin Düzeyi Sıkıı̆̆ı Hakkında Tek Merkezli Bir Çalışma}

\author{
Alparslan Merdin, Jale Yıldız, Mehmet Sinan Dal, Dicle İskender, Merih Kızıl Çakar, Ali Hakan \\ Kaya, Hikmetullah Batgi, Tuğçe Nur Yiğenoğlu, Bahar Uncu Ulu, Ali İrfan Emre Tekgündüz, Fevzi Altuntaş \\ Sağlık Bilimleri Üniversitesi Ankara Dr. Abdurrahman Yurtaslan Onkoloji Eğitim ve Araştırma Hastanesi, \\ Hematoloji Kliniği ve Kemik İliği Nakil Ünitesi, Ankara, Türkiye
}

Dergiye Ulaşma Tarihi: 07.06.2017 Dergiye Kabul Tarihi: 04.10.2017 Doi: 10.5505/aot.2018.63497

\begin{abstract}
ÖZET
GİRIŞ ve AMAÇ: Hematoloji yatan hasta servisi hastaları çeşitli kemoterapötikler, antibiyotikler ve diğer ilaçlarla tedavi edilebilirler. Hematoloji yatan hasta servisi hastaları tümör lizis önlenmesi, kemoterapötik toksisitesi önlenmesi gibi nedenlerle bazen intravenöz olarak hidrate de edilmelidirler. YÖNTEM ve GEREÇLER: Çalışma, Dr. Abdurrahman Yurtaslan Ankara Onkoloji Eğitim ve Araştırma Hastanesi Hematoloji Yatan Hasta Servisi'nde hematoloji yatan hasta servisinde 01/01/2017 (Ay / gün / yll) ve 01/15/2017 tarihleri arasında herhangi bir zamanda (01/01/2017 ve 01/15 / 2017 tarihleri dahil) takip edilmiş 49 hastayı içerdi. Hastaların potasyum düzeyleri, kreatinin düzeyleri ve hastalık türleri elektronik hasta dosyası sisteminden geriye dönük olarak kaydedildi.

BULGULAR: 49 hastanın 22( $\approx 45 \%)$ 'si yatan hasta servisindeki takiplerinde hipokalemi yaşadı. Tüm hastaların $4(\approx 8 \%)^{\prime}$ 'ü yatan hasta servisindeki takipte $3 \mathrm{mmol} / \mathrm{l}$ seviyesi altında $(<3 \mathrm{mmol} / \mathrm{l})$ hipokalemi yaşadı. Tüm hastaların $9(\approx 18 \%)^{\prime}$ 'u kreatinin seviyesi $1,2 \mathrm{mg} / \mathrm{dL}$ üzerini $(>1,2 \mathrm{mg} / \mathrm{dL})$ yaşadı.

TARTIŞMA ve SONUÇ: Hematoloji yatan hasta servisinde hipokalemi nadir olmayabilir. Hastalar böylece yatan hasta servisindeki takip sürecinde potasyum düzeyleri ve böbrek fonksiyon testleri açısından da kontrol edilmelidirler.
\end{abstract}

Anahtar Kelimeler: Hipokalemi, hematoloji, yatan hasta servisi, böbrek hastalı̆̆1

\begin{abstract}
INTRODUCTION: Hematology inpatient unit patients could be treated with various types of chemotherapeutics, antibiotics, and other drugs. Hematology inpatient unit patients should be also sometimes intravenously hydrated for the reasons such as tumor lysis syndrome prevention and chemotherapeutic toxicity prevention. Hereby, we aimed to search about the frequency of potassium and creatinine level disorders in an hematology inpatient unit.
\end{abstract}

METHODS: All the data included 49 patients who were followed in the Dr. Abdurrahman Yurtaslan Ankara Oncology Training and Research Hospital Hematology Inpatient Unit at anytime between 01/01/2017(Month/day/year) and 01/15/2017(the dates 01/01/2017 and 01/15/2017 included). The potassium levels, creatinine levels and disease types of the patients were recorded retrospectively from the electronical patient file system.

RESULTS: Of the 49 patients, $22(\approx 45 \%)$ had experienced hypokalemia during their follow-up in the inpatient unit. $4(\approx 8 \%)$ of the all patients had experienced hypokalemia below the level of $3 \mathrm{mmol} / \mathrm{l}(<3 \mathrm{mmol} / \mathrm{l})$ during the follow-up in the inpatient unit. $9(\approx 18 \%)$ of the all patients had experienced creatinine level over $1,2 \mathrm{mg} / \mathrm{dL}$ $(>1,2 \mathrm{mg} / \mathrm{dL})$.

DISCUSSION AND CONCLUSION: Hypokalemia may not be rare in hematology inpatient unit. So that, patients should also be checked for the potassium levels and renal function tests during the follow-up in the inpatient unit.

Keywords: Hypokalemia, hematology, inpatient unit, kidney disease 


\section{INTRODUCTION}

Chemotherapeutics such as cisplatin and methotrexate may cause renal failure electrolyte imbalances. May J. et al reported the incidence of renal toxicity as $9,1 \%$ of cycles in lymphoma patients who received high dose methotrexate treatment(1). Amphotericine B may also cause both electrolyte imbalances and renal toxicity. Hematology inpatient unit patients could be treated with various types of chemotherapeutics, antibiotics, and other drugs. Hematology inpatient unit patients should be also sometimes intravenously hydrated for the reasons such as tumor lysis prevention and chemotherapeutic toxicity prevention. And overhydration may result in hypokalemia. Besides, multiple myeloma (MM) could present with renal failure and hypercalcemia. And MM patients could also be hospitalised for renal failure and for diagnostic approaches in the hematology inpatient units. Hemolytic uremic syndrome (HUS) could also present with renal failure. And HUS patients could also be hospitalised with renal failure and hematological problems.

Diarrhea and vomitting may also lead to hypokalemia. Nausea and vomitting are common chemotherapy side effects. Mild hypokalemia is often asymptomatic. Mild hypokalemia could be treated with oral potassium replacement or potassium rich foods. Severe hypokalemia may cause weakness, muscle cramps, changes in electrocardiogram, constipation and neurological symptoms. Severe hypokalemia may need to be treated with intravenous potassium replacement. Hereby, we aimed to search about the frequency of potassium and creatinine level disorders in an hematology inpatient unit.

\section{MATERIALS AND METHODS}

The study included 49 patients whom were followed in the hematology inpatient unit at anytime between 01/01/2017 (Month/day/year) and 01/15/2017 (the dates 01/01/2017 and 01/15/2017 included). The study was a retrospective study. The patients who admitted to the inpatient for daily chemotherapies with same-day discharge were not included in the study. The potassium levels, creatinine levels, disease types and follow-up reasons of the patients were gathered retrospectively. The patients' previous results before the date 01/01/2017 were also taken into the analyses if the previous results were the part of the same inpatient registration which included results within the previously defined time interval. Similarly, the patients' results before 01/22/2017 were also taken into the analyses if the results were part of the same inpatient registration which included results within the previously defined time interval. Normal levels of potassium were between 3,5 $\mathrm{mmol} / \mathrm{l}$ and $5,1 \mathrm{mmol} / \mathrm{l}$. The study was approved by the Medical Speciality Education Committee of the University of Health Sciences Ankara Dr. Abdurrahman Yurtaslan Oncology Training and Research Hospital.

\section{RESULTS}

Disease distribution of the 49 patients enrolled in the study was mentioned in Table 1. Majority of the patients were leukemia and lymphoma patients (Table 1$) .27(\approx 55 \%)$ of the 49 patients were male. And $22(\approx 45 \%)$ of the 49 patients were female.

Of the 49 patients, $22(\approx 45 \%)$ had experienced hypokalemia during their followup in the inpatient unit (Table 2). Hypokalemia was treated with oral and/or intravenous potassium replacement. $4(\approx 8 \%)$ of the all patients had experienced hypokalemia below the level of $3 \mathrm{mmol} / \mathrm{l}(<3 \mathrm{mmol} / \mathrm{l})$ during the follow-up in the inpatient unit (Table 2). 9 $(\approx 18 \%)$ of the all patients had experienced creatinine level over $1,2 \mathrm{mg} / \mathrm{dL}(>1,2 \mathrm{mg} / \mathrm{dL})$ (Table 2). One patient was admitted to hospital with renal failure, anemia and thrombocytopenia. This patient was later considered as atypical hemolytic uremic sydrome. One MM patient had also acute kidney disase during the admission, and he was treated with intravenous hydration. There were three aplastic anemia patients included in the study, and two of them had experienced creatinine level over $1,2 \mathrm{mg} / \mathrm{dL}(>1,2 \mathrm{mg} / \mathrm{dL})$ during the study time interval. None of the AML patients had experienced creatinine level over $1,2 \mathrm{mg} / \mathrm{dL}$ (> $1,2 \mathrm{mg} / \mathrm{dL}) .1$ of the ALL patients had experienced creatinine level over $1,2 \mathrm{mg} / \mathrm{dL}$ (> 1,2 mg/dL). On the other side, 1 
of the NHL patients had experienced creatinine

level over $1,2 \mathrm{mg} / \mathrm{dL}(>1,2 \mathrm{mg} / \mathrm{dL})$.

Table 1. Disease distribution of the patients

\begin{tabular}{|l|l|}
\hline Disease & Number \\
\hline Acute myeloid leukemia (AML) & 13 (1 of all was “Acute promyelocytic leukemia' \\
\hline Acute lymphoid leukemia (ALL) & 7 \\
\hline Non-hodgkin's lymphoma (NHL) & 11 \\
\hline Hodgkin lymphoma (HL) & 1 \\
\hline Multiple Myeloma (MM) & 4 \\
\hline Aplastic Anemia (AA) & 3 \\
\hline Chronic lymphocytic leukemia (CLL) & 1 \\
\hline Hemolytic -Uremic Syndrome (HUS)* & 1 \\
\hline Immune Thrombocytopenic Purpura (ITP) & 1 \\
\hline Chronic myelomonocytic leukemia (CMML) & 1 \\
\hline Myelodysplastic syndrome (MDS) & 1 \\
\hline Myelofibrosis** & 1 \\
\hline Others*** & 4 \\
\hline
\end{tabular}

*The patient was considered as "atypical hemolytic-uremic syndrome" and started eculizumab therapy. She had acute kidney disease during the admission and she underwent hemodialysis.

** The patient had been under ruxolitinib treatment before the inpatient unit admission.

*** 1 of the 4 patients had pancytopenia due to vitamin B12 deficiency, 1 other patient was also under investigation for the etiology of pancytopenia. 1 patient had a diagnostic history of AML; but the clinical findings during the submission seemed like CMML, he was also under investigation. The last patient of this group presented with MM findings, he was also under investigation. 
Table 2: Percentage of patients whom experienced low potassium level or high creatinine level during the follow-up period in the inpatient unit.

\begin{tabular}{|l|l|l|}
\hline & Number(N) $^{*}$ & Percentage (\%) \\
\hline Pypokalemia with & 22 & $\approx 45 \%$ \\
\hline $\begin{array}{l}\text { Hypokalemia with } \\
\text { Potassium level }<3 \mathrm{mmol} / \mathrm{l}\end{array}$ & 4 & $\approx 8 \%$ \\
\hline Creatinine level $>1,2 \mathrm{mg} / \mathrm{dL}$ & & $\approx 18 \%$ \\
\hline
\end{tabular}

* Total number of the patients is 49

\section{DISCUSSION}

Intravenous fluid hydration may be necessary for hematology patients in the inpatient unit. Some of the well known reasons for intravenous hydration are to protect the kidney from side effects of toxic chemotherapies, to treat renal failure due to multiple myeloma and to prevent tumor lysis syndrome. Intravenous hydration might also contribute to decrease potassium levels in hematology patients. Paice BJ et al. reported $21 \%$ percentage of hypokalemia development during hospitalization, and $5.2 \%$ of hypokalemia with serum potassium level less than $3 \mathrm{mmol} / \mathrm{l}$ development during hospitalization (2). On the other side, our data shows a higher rate of hypokalemia development in hematology inpatient hospitalizations. In our study, hypokalemia was seen in approximately $45 \%$ of the patients. Vitamin B12 replacement could also induce hypokalemia due to influx of potassium into the newly proliferated erythrocytes. We had only one patient admitted due to pancytopenia secondary to vitamin B12 deficiency during the study period. But that patient did not have hypokalemia in the defined time interval. Besides, vitamin B12 replacement is usually given in the outpatient in our hospital. It was also reported about a possible association between monocytic or myelomonocytic leukemia and hypokalemia (3).

Kidney disease is one of the morbidity reasons in MM. Kyle RA et al. reported the percentage of the initially MM diagnosed patients with a serum creatinine level of 2 $\mathrm{mg} / \mathrm{dL}$ or more as $19 \%$ (4). We had a MM patient admitted for acute kidney disease. We had also another patient with MM suspicion who had experienced high creatinine levels during the study time interval. Even some chemotherapeutics and some hematological diseases could also cause acute kidney injury. Cyclosporine used in aplastic anemia could cause kidney toxicity (5). Cyclosporine drug levels should be measured regularly in aplastic anemia patients. Sepsis, which might also develop in hematological malignacies, could also be associated with kidney injury (6$9)$. Both of the two aplastic anemia patients, who had experienced creatinine level over > $1,2 \mathrm{mg} / \mathrm{dL}$ during the study time interval, used multiple antibiotherapy.

In conclusion, hypokalemia and renal disturbances may not be very rare in hematology inpatient unit. So that, patients should also be checked for the potassium levels and renal function tests during the follow-up in the inpatient unit.

Conflict of interest: None 


\section{REFERENCES}

1. May J, Carson KR, Butler S, Liu W, Bartlett NL, Wagner-Johnston ND. High Incidence of Methotrexate Associated Renal Toxicity in Patients with Lymphoma: A Retrospective Analysis. Leuk Lymphoma. 2014 Jun;55(6):1345-9.

2. Paice BJ, Paterson KR, Onyanga-Omara F, Donnelly T, Gray JMB, Lawson DH. Record linkage study of hypokalemia in hospitalized patients. Postgrad Med J 1986; 62:187-91

3. Muggia FM, Heinemann HO, Farhangi M, Osserman EF. Lysozymuria and renal tubular dysfunction in monocytic and myelomonocytic leukemia. Am J Med 1969; 47: 351-66.

4. Kyle RA, Gertz MA, Witzig TE, Lust JA, Lacy MQ, Dispenzieri A, et al. Review of 1027 patients with newly diagnosed multiple myeloma. Mayo Clin Proc 2003; 78: 21-33.

5. Burdmann EA, Andoh TF, Yu L, Bennett WM. Cyclosporine nephrotoxicity. Semin Nephrol 2003; $23: 465-476$.

6. Bagshaw SM, George C, Bellomo R, ANZICS Database Management Committee. Early acute kidney injury and sepsis: a multicentre evaluation. Crit Care. 2008; 12:R47.

7. Majumdar A. Sepsis-induced acute kidney injury. Indian J Crit Care Med. 2010 Jan;14(1):14-21.

8. Alobaidi R, Basu RK, Goldstein SL, Bagshaw SM. Sepsis-associated acute kidney injury. Semin Nephrol. 2015 Jan;35(1):2-11.

9. Bilgili B, Haliloğlu M, Cinel İ. Sepsis and Acute Kidney Injury. Turk J Anaesthesiol Reanim. 2014 Dec;42(6):294-301. 